\title{
Look who's talking: Means of interpersonal communication between librarians and library users
}

\author{
Irmawan Rahyadi ${ }^{1}$, Masyhur Dungcik ${ }^{2}$, Misroni $^{2}$, Nurul Jannah ${ }^{2}$ and Irsyad Ghifari ${ }^{1}$ \\ \{irmawan.rahyadi@binus.edu ${ }^{1}$ \} \\ Communication Department, BINUS Graduate Program - Master of Strategic Marketing \\ Communication, Bina Nusantara University, Jalan Kebon Jeruk No. 27, Jakarta Barat 11530, DKI \\ Jakarta, Indonesia ${ }^{1}$, Library and Information Science Department-Adab, and Humanities Faculty, \\ Raden Fatah State Islamic University, Jl. Prof. K. H. Zainal Abidin Fikri No. KM.3,5, South \\ Sumatera, Indonesia ${ }^{2}$
}

\begin{abstract}
This article is aimed to explore the interpersonal communication of library staff in library service. Satisfaction of library users and the correlation interpersonal communication of library staff to the satisfaction of library users of library service. This research used quantitative research method. The data collecting technique used observation, questionnaire, and documentation. The population in this research consists of library service visitors $(\mathrm{N}=81.896)$, then it is taken visitors for sampling $(n=99)$. The chosen sampling technique used a simple random sample, while data measurement used the Likert scale. The validity test applied the productmoment correlation formula, while the reliability test uses the Alpha Cronbach formula. The result shows that interpersonal communication of library staff in library service belongs to high category. The satisfaction of library users in library service is in the high class. There is a positive correlation between the interpersonal communication of library staff and the joy of library users in library service.
\end{abstract}

Keywords: interpersonal communication, library, librarian, quantitative method, questionnaire.

\section{Introduction}

Since the COVID-19 pandemic hit the world, many libraries responded swiftly by offering remote services (1). Direct services of the library when users ask for help finding a specific book, immediate benefits of the library decrease as libraries close their doors in recent times. The vital purpose of the library is to provide satisfaction to the users of the services, facilities, and collections contained in the library. However, service delivery to the users' needs to run smoothly; otherwise, all goals will be useless. This means that visitor satisfaction will be created if the services provided by the library are suitable. Decent service will give birth to the closeness between library staff and visitors so that the collections, services, and library facilities can be maximally utilized.

Ideally, libraries should always provide and improve good service and provide convenience for visitors. The library users will be happy to come to the library if the library staff serve with a warm welcome, provide instructions patiently, friendly, and sensitive to the needs of its users $(2,3)$. All of this can be realized if all aspects in the library support each other and work in harmony, harmony, and balance. 
Professionally, high communication skills will lead to success in work. In a library, library staff has a lot to do with visitors who find the information they need, especially in the circulation section. Having adequate communication skills, helping their tasks that can build and instill a positive image in the library (4).

Communication is a form of human interaction that influences each other, intentionally or unintentionally. There are several types of communication, one of which is interpersonal communication. Interpersonal communication is the delivery of messages by one person and receipt of notifications by another person or a small group of people, with various effects and with the opportunity to provide immediate feedback (5-7). In the library, communication activities are an essential activity, especially for library staff, such as communication between users and library staff who provide information services. All forms of assistance that exist in the library, the transaction's success is not only measured by the information provided but also by the positive and negative effects of the interaction of library users or library staff. What kind of positive and negative attitudes of the library staff are accepted by the visitors is an essential factor in measuring visitor satisfaction with the services provided $(8,9)$.

Satisfaction is the level of a person's feelings statement produced and the comparison of the perceived usefulness of the product with the expectations of the product. If a person fulfils the desired information needs in a library, then he will feel satisfied and will meet his information needs in the same place repeatedly. The users will likely invite other people to come to the same library.

The South Sumatra Provincial Library Office is one of the information centres. As an information centre, it is better to provide good service to its users constantly, so users are satisfied with the services offered. Therefore, satisfaction, needs, and services are essential to describe the library as having carried out the objectives of a library. Based on the background above, the study aims to explore the lack of communication skills that may affect visitor satisfaction, and lack of attention made by library staff in examining visitor request.

\section{Research Methods}

This research uses quantitative research methods. Quantitative research can be defined as a research method based on the philosophy of positivism, used to research specific populations or samples, data collection using research instruments, quantitative/statistical data analysis to test predetermined hypotheses. The research design used is a non-experimental type, using correlational research. Correlational research aims to examine the relationship between two or more variables (10). The time used starts from preparing the research proposal to the implementation of the research, which is four months. This research was conducted at the Library Office of South Sumatra Province.

This study applied primary data sources and secondary data sources:

a. Primary Data Sources

Primary data comes from data obtained by distributing questionnaires to respondents, namely library visitors at the Library Office of South Sumatra Province.

b. Secondary Data Sources

Secondary data obtained from media sourced from lecture books or books that explain interpersonal communication and visitor satisfaction, journals that describe interpersonal communication and visitor satisfaction, research results that discuss interpersonal 
communication and visitor satisfaction, websites that contain interpersonal communication and visitor satisfaction, and so on related to the problems raised in this study.

The data collection techniques used in this research are questionnaire, observation, and documentation. The population is all individuals who are the source of sampling. The population in this study were visitors who visited the South Sumatra Provincial Library Service. From January 2018 - December 2018, the number of visitors who visited was 81896. The total population taken in this study was the average number in one month, so that the number of visitors was 6825 . The sample is a portion of all individuals who are the object of research. This research uses a simple random sampling technique. Simple random sampling is the simplest technique because the sampling of population members is done randomly without paying attention to the strata in the population. Finding the sample size, this study used the Slovin formula proposed by Husein Umar, with an error rate of $10 \%$. The variable measurement scale used in this study is a Likert scale and is made in a checklist.

Table 1. Item measurement and statement weight.

\begin{tabular}{ll}
\hline Statement & Weight \\
\hline Strongly agree & 5 \\
Agree & 4 \\
Somewhat Agree & 3 \\
Disagree & 2 \\
Strongly Disagree & 1 \\
\hline
\end{tabular}

Research variables are anything in the form determined by the researcher to study, so that information about it is obtained, then conclusions are drawn. In a study, there are two variables, namely the independent variable and the dependent variable. Independent variables (complimentary) are variables that explain or influence other variables, while dependent variables (dependent) are variables that are affected by independent (free) variables. The independent variable $(\mathrm{X})$ in this study is the interpersonal communication variable of library staff at the South Sumatra Provincial Library Service. In contrast, the dependent variable (Y) is visitors' satisfaction at the Library Service of South Sumatra Province. Variables, sub-variables, and indicators in this study are as follows:

Table 2. Variable communication and users' satisfaction.

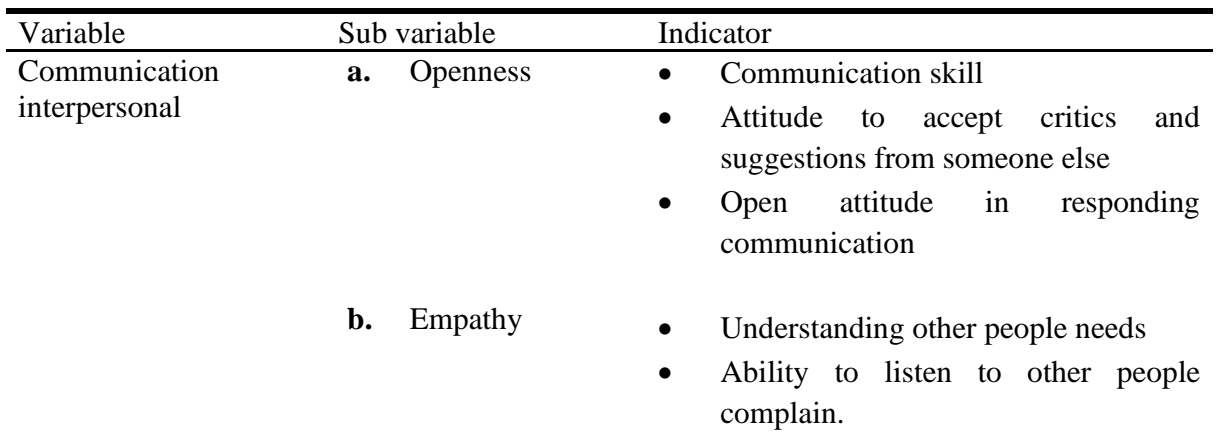


c. Supportive

- Understanding a problem from other attitude people perspective

- Commitment on supporting communication process

- Good attitude towards communication

d. Positive attitude

- Ability in problem-solving

- Commitment on supporting communication process

- Good attitude towards communication

- $\quad$ Ability in problem-solving

e. Fairness

- Relatively position oneself among others.

- Realizing other people rights

- Realizing the significance of another present

User satisfaction a. Tangibles

- Room cleanliness and comfort

- $\quad$ Tidiness, correctness, and cleanliness of staffs' appearances

- $\quad$ Adequate facility

b. Reliability

- Ability in prioritizing users' needs

- Ability in giving speedy, decent, and easy service

- Ability to give solution

- Ability in giving necessary information to users

c. Responsiveness

- $\quad$ Ability in giving speedy, decent, and easy service

- $\quad$ Ability in giving understanding

- Giving fair service

d. Assurance

- Ability in decent communication

- Knowledge in time-efficient service

Validity is an index that shows the measuring instrument measures what is being measured. This validity concerns the accuracy of the instrument. To find out whether the questionnaire 
compiled is valid/valid, it is necessary to test the correlation between the score (value) of each question item using the Product Moment Correlation formula.

Reliability (trust) refers to the notion of whether the instrument can measure something that is measured consistently over time. The keywords for the qualification requirements of a measurement instrument are consistency, consistency, or not change. To measure the reliability of the questionnaire used, a reliability analysis was carried out based on the Cronbach Alpha coefficient.

The collected data were analyzed quantitatively, namely by collecting the results of field research, especially questionnaires. The data is analyzed following tabulating data from the questionnaire, then describe the correlation. Furthermore, the percentage calculation is carried out. For each answer from the respondent, the highest score will be five (5) and the lowest one (1). The sum of the scores for each question will be divided by the number of respondents so that an average score (value) will be obtained. Hypothesis testing was done using the Product Moment formula. In contrast to the validity test, in this data analysis, the processed data is the sum of the total answer scores of each respondent. The next stage is counting the correlation coefficient as an index or number used to measure the degree of the relationship, including the strength of the relationship and the shape/direction of the relationship. For the power of the relationship, the value of the correlation coefficient is between -1 and +1 . To determine the closeness of the relationship/correlation between interpersonal communication variables and visitor satisfaction, a correlation coefficient symbolized " $r$ " is used.

\section{Result and discussion}

Data gathering was conducted on 99 visitors who visited the South Sumatra Provincial Library Service to answer research objectives. Researchers collected data from respondents through distributing questionnaires. Researchers provided 30 statements consisting of 15 ideas for the variable $(\mathrm{X})$, namely interpersonal communication, and 15 words for the variable $(\mathrm{Y})$, namely visitor satisfaction. The distribution of questionnaires to respondents was carried out for three (3) days, 25-27 February 2019, at the South Sumatra Provincial Library Service to find out how the interpersonal communication of library staff at the South Sumatra Provincial Library Service, to find out how the satisfaction of visitors at the South Sumatra Provincial Library Service, and how the interpersonal communication relationship between library staff and visitor satisfaction.

\subsection{Test results of the validity and reliability of the instrument}

Before distributing the questionnaire to 99 respondents, the validity and reliability test were applied on 30 respondents outside the sample. It could be known whether the statements that had been compiled were valid, consistent, and reliable or not. For the level of validity, the researcher used the significance test by comparing rcount and rtable values utilizing the degree of freedom (df) formula to determine the rtable. The procedure is $\mathrm{df}=\mathrm{n}-\mathrm{k}$, where $\mathrm{n}$ is the number of samples and $\mathrm{k}$ is the number of constructs (number of variables). Thus, it can be calculated that $\mathrm{df}=30-2$ $=28$ with an error level of 0.1 . If you look at the table $\mathrm{r}$ (simple correlation coefficient), rtable is 0.306. If rcount on each item of the statement is more significant than rtable, then each item of the information is declared valid, and vice versa. In testing the validity test, the calculations are shown in the following table: 
Table 3. Result of the validity test of the questionnaire for the variable (x).

\begin{tabular}{llll}
\hline $\begin{array}{l}\text { Statement } \\
\text { numbering }\end{array}$ & $\mathrm{R}_{\text {count }}$ & $\mathrm{R}_{\text {table }}$ & Description \\
\hline 1 & 0,701 & 0,306 & Valid \\
2 & 0,460 & 0,306 & Valid \\
3 & 0,350 & 0,306 & Valid \\
4 & 0,451 & 0,306 & Valid \\
5 & 0,456 & 0,582 & Valid \\
6 & 0,441 & 0,306 & Valid \\
7 & 0,539 & 0,306 & Valid \\
8 & 0,663 & 0,306 & Valid \\
9 & 0,669 & 0,306 & Valid \\
10 & 0,396 & 0,306 & Valid \\
11 & 0,643 & 0,306 & Valid \\
12 & 0,779 & 0,306 & Valid \\
13 & 0,742 & 0,306 & Valid \\
14 & 0,723 & 0,306 & Valid \\
15 & 0,651 & 0,306 & Valid \\
\hline
\end{tabular}

Based on table 3 above, it can be explained that the $r$ table value, when viewed from the significance level of 0.1 , is 0.306 . So from the results of the validity test on each item of the statement on the variable $(\mathrm{X})$, interpersonal communication above, when viewed from the $\mathrm{r}_{\mathrm{ating}}$,

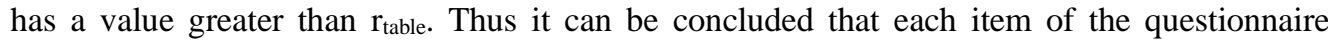
statement for the variable $(\mathrm{X})$ interpersonal communication is all declared valid.

Table 4. Result of the validity test of the questionnaire for the variable (x).

\begin{tabular}{llll}
\hline $\begin{array}{l}\text { Statement } \\
\text { numbering }\end{array}$ & $\mathrm{R}_{\text {count }}$ & $\mathrm{R}_{\text {table }}$ & Description \\
\hline 16 & 0,800 & 0,306 & Valid \\
17 & 0,674 & 0,306 & Valid \\
18 & 0,669 & 0,306 & Valid \\
29 & 0,645 & 0,306 & Valid \\
20 & 0,556 & 0,582 & Valid \\
21 & 0,521 & 0,306 & Valid \\
22 & 0,606 & 0,306 & Valid \\
23 & 0,472 & 0,306 & Valid \\
24 & 0,620 & 0,306 & Valid \\
25 & 0,720 & 0,306 & Valid \\
26 & 0,548 & 0,306 & Valid \\
27 & 0,522 & 0,306 & Valid \\
28 & 0,376 & 0,306 & Valid \\
29 & 0,614 & 0,306 & Valid \\
30 & 0,586 & 0,306 & Valid \\
\hline
\end{tabular}


Based on table 4 above, it can be explained that the $r$ table value, when viewed from the significance level of 0.1 , is 0.306 . So from the results of the validity test on each item of the statement on variable (Y), user satisfaction above when viewed from rcount has a value greater than rtable. Thus it can be concluded that each item of the questionnaire statement for variable (Y) visitor satisfaction is all declared valid.

\subsection{Data description}

The data obtained are then analyzed, and the percentage calculations are carried out in each statement item. In variable $(\mathrm{X})$ interpersonal communication, several sub-variables help determine the interpersonal communication of library staff at the South Sumatra Provincial Library Service: openness, empathy, supportive attitude, positive attitude, and equality.

Response description sub variable openness shown in the following is the respondent's statement regarding the indicators of the openness sub variable, which will be explained in the following table:

Table 5. Response descriptions sub variable openness

\begin{tabular}{lllllcl}
\hline $\begin{array}{l}\text { Statement } \\
\text { numbering }\end{array}$ & & \multicolumn{5}{c}{ Frequency } \\
\cline { 2 - 7 } & & S & SS & D & VD $^{1}$ & Total \\
\hline 1 & 11 & 42 & 40 & 5 & 1 & 99 \\
2 & 9 & 4 & 37 & 7 & 1 & 99 \\
3 & 17 & 34 & 42 & 6 & 0 & 99 \\
Total & 37 & 121 & 119 & 18 & 2 & 297 \\
\hline
\end{tabular}

Based on the calculation of table 5 above, it can be explained that the results of the total number of respondents' responses to openness through the three statement items, namely: point 1) library staff are willing to convey important information to users, 2) library staff receive criticism and input from users, 3) library staff Communicating openly with users, the average results obtained were $12.46 \%$ Very Satisfied, 40.74\% Satisfied, 40.07\% Somewhat Satisfied, $6.06 \%$ Dissatisfied, and 0 Very Dissatisfied, 67\%. When viewed from the results above, the highest result is the Satisfied answer, namely $40.74 \%$.

Interpersonal communication of library staff at the Library Office of South Sumatra Province based on the results of data processing that has been carried out obtained an average value of 3.64 with a percentage of $3.68 \%$, it can be concluded that the interpersonal communication of library staff in the Library Service of South Sumatra Province is high. Satisfaction of visitors in the Library Office of South Sumatra Province based on the results of the data processing that has been carried out obtained an average value of 3.75 with a percentage of $3.79 \%$, it can be concluded that the satisfaction of visitors in the Library Service of South Sumatra Province is high.

${ }^{1}$ VS=Very Satisfied, S=Satisfied, SS=Somewhat Satisfied, D=Dissatisfied, VD=Very Dissatisfied 
Meanwhile, for the analysis of the relationship between library staff interpersonal communication and visitor satisfaction at the South Sumatra Provincial Library Service, researchers used Product Moment correlation analysis. The correlation coefficient was 0.882 , with an $r$ table at a $10 \%$ error level of 0.256 . Thus, the correlation coefficient value is greater than the value of the $r$ table $(0.882>0.256)$. So, it can be concluded that the null hypothesis (Ho) is rejected, while the alternative idea $(\mathrm{Ha})$ is accepted. This means that there is a relationship between the interpersonal communication of library staff with visitor satisfaction at the South Sumatra Provincial Library Service. By obtaining a correlation coefficient value of 0.882 , it is included in the category in the range of $0.80-1,000$. The interpretation is a robust correlation between the library staff interpersonal communication variable $(\mathrm{X})$ and the visitor satisfaction variable $(\mathrm{Y})$. This indicates that the interpersonal communication of library staff does have something to do with the satisfaction level of visitors at the South Sumatra Provincial Library Service $(11,12)$.

\section{Conclusion}

So it can be concluded that through the openness sub variable, library staff at the South Sumatra Provincial Library Service already have an open attitude towards users in interpersonal communication. Based on the formulation of the problems that have been compiled and data analysis and findings, conclusions can be formulated about what the interpersonal communication of library staff at the Library Service of South Sumatra Province is, what is the satisfaction of the visitors at the South Sumatra Provincial Library Service, and how the interpersonal communication relationship between library staff and visitor satisfaction at the South Sumatra Provincial Library Service. Based on the analysis and findings and conclusions outlined in this study, it proposes suggestions since the satisfaction of visitors in the Library Office of South Sumatra Province is already high, so that library staff must maintain and increase visitor satisfaction both in terms of interpersonal communication of library staff and from other aspects (13)(14). Library visitors are expected to establish contact with library staff, whether asking questions when experiencing difficulties or providing input to library staff $(15,16)$. It is hoped that further researchers can develop this research by using interpersonal communication theory and other visitor satisfaction theories that are the topic of discussion to be studied $(17,18)$. And it is advisable to increase the number of reference sources in the library study, such as books or research journals (19),(20,21).

\section{References}

[1] Kung J. 5 things your library can do for you (during and after the pandemic)| University Affairs. 2021; Available from: https://www.universityaffairs.ca/career-advice/graduate-matters/5-thingsyour-library-can-do-for-you-during-and-after-the-pandemic/

[2] Mcharazo AA, Olden A. Fifty years of Tanzania's national/public library service. Alexandria J Natl Int Libr Inf Issues. 2016 Aug;26(2):136-44.

[3] Noh Y, Hong H-J. A study on the relationship between library service and digital competence. J Librariansh Inf Sci [Internet]. 2021 Apr 27 [cited 2021 May 12];096100062110089. Available from: http://journals.sagepub.com/doi/10.1177/09610006211008962

[4] Andrews J, Chapman K-C. The British Library in China: Connecting through culture and learning. Alexandria J Natl Int Libr Inf Issues. 2020 Apr;30(1):22-31. 
[5] Burgers C, Beukeboom CJ. Stereotype Transmission and Maintenance Through Interpersonal Communication: The Irony Bias. Communic Res. 2016 Apr 1;43(3):414-41.

[6] Carassa A, Colombetti M. Interpersonal Communication as Social Action. Philos Soc Sci. 2015 Jul 13;45(4-5):407-23.

[7] Kalogeropoulos A, Albæk E, de Vreese CH, Van Dalen A. The predictors of economic sophistication: Media, interpersonal communication and negative financial experiences. Eur $\mathrm{J}$ Commun. 2015 Aug 6;30(4):385-403.

[8] Morgan AU, D’Alonzo BA, Dupuis R, Whiteman ED, Kallem S, McClintock A, et al. Public Library Staff as Community Health Partners: Training Program Design and Evaluation. Health Promot Pract. 2018 May 1;19(3):361-8.

[9] Roberts N, Konn T. Continuing education and training for academic library staff. J Librariansh Inf Sci. 1989;21(2):109-28.

[10] Konakli T. Effects of self-efficacy on social entrepreneurship in education: A correlational research. Res Educ. 2015 Nov 1;94(1):30-43.

[11] Oh DG. Analysis of the factors affecting volunteering, satisfaction, continuation will, and loyalty for public library volunteers: An integrated structural equation model. J Librariansh Inf Sci. 2019 Dec 1;51(4):894-914.

[12] Alam MJ. Effects of service quality on satisfaction in Eastern University Library, Bangladesh. IFLA J. 2020;

[13] Chow J. Realising the potential of user surveys for improving academic libraries: The case of St John's College, Cambridge. J Librariansh Inf Sci. 2019 Sep;51(3):689-701.

[14] Cha SH, Kim TW. The role of space attributes in space-choice behavior and satisfaction in an academic library. J Librariansh Inf Sci. 2020 Jun 1;52(2):399-409.

[15] Dukić G, Dukić D. An analysis of job satisfaction among Croatian librarians supports library human resource management. J Librariansh Inf Sci. 2014 Dec 10;46(4):289-98.

[16] Umukoro IO, Tiamiyu MA. Determinants of e-library services' use among university students: A study of John Harris Library, University of Benin, Nigeria. J Librariansh Inf Sci. 2017 Dec 1;49(4):438-53.

[17] Šimunić Z, Tanacković SF, Badurina B. Library services for incarcerated persons: A survey of recent trends and challenges in prison libraries in Croatia. J Librariansh Inf Sci. 2016 Mar 1;48(1):72-89.

[18] Xiao L. Innovative application of knowledge management in the organizational restructuring of academic libraries: A Peking University Library case study. IFLA J [Internet]. 2020 Mar 1 [cited 2021 May 12];46(1):15-24. Available from: http://library.babcock.edu.ng/

[19] Jones-Edman G, Lewis JC, Worrell-Johnson B. Keeping up with best practices: Library exhibitions at a university library in a small island developing state. Alexandria J Natl Int Libr Inf Issues. 2019 Apr;29(1-2):59-76.

[20] Cahill M, Joo S, Howard M, Ingraham Dwyer J, King-Oaks K, Yates B. What is storytime good for and what makes storytime suitable? A survey of public library directors. J Librariansh Inf Sci. 2020 Dec 1;52(4):1000-14.

[21] Bamidele IA, Omeluzor SU, Imam A, Amadi HU. Training of Library Assistants in Academic Library. SAGE Open [Internet]. 2013 Sep 17 [cited 2021 May 12];3(3):215824401350396. Available from: http://library.babcock.edu.ng/ 